\title{
Activity of minocycline against Toxoplasma gondii infection in mice
}

\author{
Hernan R. Change*, Raymonde Comte, Pierre-François Piguet and \\ Jean-Claude Pechère* \\ ${ }^{a}$ Departments of Microbiology and ${ }^{b}$ Pathology, University of Geneva Medical School, \\ C.M.U., 9 av. de Champel, 1211 Geneva 4, Switzerland
}

\begin{abstract}
The chemotherapeutic activity of minocycline, a semi-synthetic tetracycline analogue, was evaluated in a murine model of toxoplasmosis. A lethal acute toxoplasmosis was produced by injecting $10^{5}$ tachyzoites of the RH strain of Toxoplasma gondii into the peritoneal cavities of Swiss-Webster mice. When infected mice were treated once daily for 12 days, starting $2 \mathrm{~h}$ after challenge, the survival and cure rates were $100 \%$ and $40 \%$ respectively after minocycline alone $(100 \mathrm{mg} / \mathrm{kg}$ per day), $0 \%$ and $0 \%$ after pyrimethamine alone $(8.5 \mathrm{mg} / \mathrm{kg}$ per day), and $100 \%$ and $50 \%$ after combination of the two drugs at the same dosages. Absolute survival and cure with minocycline were observed when mice were treated with two daily doses of $100 \mathrm{mg} / \mathrm{kg}$ for 12 days. Mice chronically infected with a low virulent strain of $T$. gondii (Me49) showed a significant reduction in the number of brain cysts after three weeks of treatment with $50 \mathrm{mg} / \mathrm{kg}$ per day of minocycline. Minocycline serum levels after a single oral administration of $50 \mathrm{mg} / \mathrm{kg}$ or $100 \mathrm{mg} / \mathrm{kg}$ to normal mice, peaked at $1.8 \mathrm{mg} / \mathrm{l}$ and $10 \mathrm{mg} / \mathrm{l}$ after $1 \mathrm{~h}$, respectively, and showed an extended half-life.
\end{abstract}

\section{Introduction}

Encephalitis due to Toxoplasma gondii has become a frequent infectious complication in patients suffering from the acquired immunodeficiency syndrome (McCabe \& Remington, 1988). Treatment with the synergistic combination of pyrimethamine and sulphadiazine (or a trisulphapyrimidine) (Leport et al., 1988) is followed by an initial good response subsequently hampered by a number of side effects (Glatt, Chirgwin \& Landesman, 1988), mainly due to the sulphonamide component of the combination. Moreover, this treatment is not able to eradicate the tissue cyst form of the parasite, which is found in the organs of the infected individuals (Remington \& Cavanaugh, 1965). Therefore, there is a clear need for the development of new compounds for treating toxoplasmosis.

The in-vivo therapeutic effect of the semi-synthetic tetracycline analogues, doxycycline and minocycline against acute murine infections with $T$.gondii have been previously described (Chang, Comte \& Pechère, 1990; Tabbara, Sakuragi \& O'Connor, 1982). In the studies reported here, we assessed the activity of minocycline in acute and chronic murine models of toxoplasmosis.

-Corresponding author. 


\section{Materials and methods}

Animals

Female Swiss-Webster mice (Madörin AG, Füllinsdorf, Switzerland) at six to eight weeks of age and weighing $25 \pm 1 \mathrm{~g}$ were used.

\section{Antimicrobial agents}

Minocycline hydrochloride was provided in powder form by Laboratoires Lederle, Oullins, France, and prepared each day in sterile distilled water. Pyrimethamine was provided in powder form by F. Hoffmann-La Roche \& Cie, S. A., Basel, Switzerland, and was dissolved in $95 \%$ ethanol and diluted in sterile distilled water. In studies in which pyrimethamine was used in combination with minocycline the solutions were mixed prior to use.

\section{T. gondii strains}

The highly virulent RH strain of $T$. gondii was used for acute infection. Tachyzoites were obtained from the peritoneal cavities of infected mice as described previously (Chang \& Pechère, 1987). For chronic infection, the Me49 strain, a low virulent strain, of $T$. gondii was used (kindly provided by Prof. J. S. Remington, CA, USA).

\section{Animals models}

Acute toxoplasmosis. Mice were infected intraperitoneally (ip) with $10^{5}$ tachyzoites of the RH strain of $T$. gondii, i.e., 50,000 times the 100\% lethal dose (Chang \& Pechère, 1987) in $0.5 \mathrm{ml}$ of sterile $0.9 \% \mathrm{NaCl}$. Animals were randomly allocated in groups of ten with free access to food and water. At the end of the $\mathbf{3 0}$ day study period the surviving mice were sacrificed and autopsied. Peritoneal exudates were examined microscopically $(\times 400)$ for the presence of tachyzoites. When parasites could not be seen the brain was homogenized and inoculated into two new mice. The donor was considered 'cured' if the two recipient mice survived 30 days after injection and no $T$. gondii were present at autopsy.

Chronic toxoplasmosis. Mice were infected ip with 20 cysts of the Me49 strain of $T$. gondii in $0.5 \mathrm{ml}$ of sterile $0.9 \% \mathrm{NaCl}$. Prior to starting the experiments five mice were randomly assessed for the presence of brain cysts in order to confirm that chronic infection was established. Animals were used four months later. At the end of the 21 day study period the brains of the animals were aseptically removed and $5 \mathrm{ml}$ of sterile $0.9 \% \mathrm{NaCl}$ added. The organs were successively passaged through $18-\mathrm{G}$ and $20-\mathrm{G}$ needles with a $10-\mathrm{ml}$ plastic syringe to homogenize them. The number of cysts per brain was determined by light microscopy of $25 \mu \mathrm{l}$ aliquots and scanning the entire brain preparation.

\section{Therapeutic regimens}

For acute infection, oral minocycline was started $2 \mathrm{~h}$ after ip infection and was given for 12 days. Treatment was administered every $12 \mathrm{~h}$ or $24 \mathrm{~h}$. Pyrimethamine alone was administered by gavage, and pyrimethamine was also administered orally when combined with minocycline. For chronic infection, therapy was started four months 
after infection and given once daily by gavage for three weeks. The brains were then removed and the number of brain cysts calculated, as previously described. Control groups of infected mice (for acute and chronic infections) received only distilled water and uninfected mice received drug treatment in all investigations.

\section{Histopathology}

The organs (liver, spleen, kidneys, bowel, lungs and brain) of untreated and treated acutely infected mice were removed five days after challenge, fixed in $10 \%$ buffered formalin and embedded within paraffin. Sections were cut at $5 \mu \mathrm{m}$ and stained with haematoxylin and eosin, and used for histological analysis. The same analysis was carried out at day 17 and day 30 after challenge in the treated group (no control animals were available by this time). Normal uninfected mice served as negative controls.

\section{Levels of minocycline in serum}

Groups of thirty normal fasting $(1 \mathrm{~h})$ mice were given by gavage a single dose of 50 or $100 \mathrm{mg}$ of minocycline per $\mathrm{kg}$; and blood samples were collected at $0.5,1,2,4,7,10,13$, 16,20 and $24 \mathrm{~h}$ after treatment. Serum levels of minocycline were assessed with a microbiological assay by using Staphylococcus aureus ATCC 6538P, as test organism. The elimination rate constant $(\beta)$ was calculated from the linear regression of serum concentration-versus-time data. Half-life $\left(T_{1 / 2}\right)$ was calculated by employing the following equation: $T_{1 / 2 \beta}=\ln 2 / \beta$.

\section{Statistics}

For survival rates statistical analysis was performed by using the chi square test. Other differences between test and control groups were analysed using Student's $t$-test. A $P$ value of $<0.05$ was considered significant.

\section{Results}

\section{Acute toxoplasmosis}

All infected untreated control mice died from acute toxoplasmosis $5 \pm 1$ days after challenge (Table I). All minocycline-treated infected mice survived. A dose of $100 \mathrm{mg} / \mathrm{kg} /$ day of minocycline given for 12 days protected $100 \%$ of the mice $(P<$ 0.001 , compared with untreated controls) with a cure rate of $40 \%$, according to brain sub-inoculations. When this dose of minocycline was given in combination with pyrimethamine $(8.5 \mathrm{mg} / \mathrm{kg} / \mathrm{day}), 100 \%$ of animals survived with a cure rate of $50 \%$. Pyrimethamine $(8.5 \mathrm{mg} / \mathrm{kg} /$ day) alone was ineffective in protecting the animals. Complete protection $(100 \%)$ with total cure was obtained with minocycline in $100 \mathrm{mg} / \mathrm{kg}$ doses given every $12 \mathrm{~h}$.

Histopathological studies were performed with a series of infected animals treated with $200 \mathrm{mg} / \mathrm{kg} /$ day of minocycline (Figure 1). Five days after challenge, infected control animals showed marked inflammation and extensive necrosis in the liver, spleen, kidney and lungs; the treated mice showed less inflammation and necrosis was not observed. Seventeen days after challenge, the treated mice showed even less 
Table I. Therapeutic effects obtained with minocycline and pyrimethamine on murine acute toxoplasmosis

\begin{tabular}{|c|c|c|c|}
\hline $\begin{array}{l}\text { Drug (dose (mg/kg } \\
\text { per day)) }\end{array}$ & $\begin{array}{l}\text { Time to death for } \\
50 \% \text { of mice (days) }\end{array}$ & $\begin{array}{l}\text { No. of survivors/ } \\
\text { no. of mice (\%) }\end{array}$ & $\begin{array}{l}\text { No. of survivors } \\
\text { cured }(\%)\end{array}$ \\
\hline $\begin{array}{l}\text { None } \\
\text { Minocycline }\end{array}$ & $5 \pm 1$ & $0 / 30(0)$ & \\
\hline 25 & 9 & $3 / 10(30)$ & $0 / 3 \quad(0)$ \\
\hline 50 & 15 & $5 / 10(50)$ & $2 / 5 \quad(40)$ \\
\hline 100 & & $10 / 10(100)$ & $4 / 10(40)$ \\
\hline 200 & & $10 / 10(100)$ & $10 / 10(100)$ \\
\hline $\begin{array}{l}\text { Minocycline }(100)+ \\
\text { pyrimethamine }(8.5)\end{array}$ & . & $10 / 10(100)$ & $5 / 10(50)$ \\
\hline Pyrimethamine (8.5) & 8 & $0 / 10(0)$ & \\
\hline
\end{tabular}

inflammation in the organs examined, and by day 30 inflammation had completely resolved.

\section{Chronic toxoplasmosis}

No spontaneous death was observed during the entire period of study. The number of brain cysts in the mice treated with minocycline at a dose of $50 \mathrm{mg} / \mathrm{kg} /$ day for 21 days was significantly lower $(P<0.02)$ as compared to the untreated control mice (Table II).

Levels of minocycline in the serum of mice

Minocycline attained peak serum concentrations of 1.8 and $10 \mathrm{mg} / 1 \mathrm{~h}$ after a single dose of 50 or $100 \mathrm{mg} / \mathrm{kg}$, respectively. The calculated serum half-lives were 5.4 and
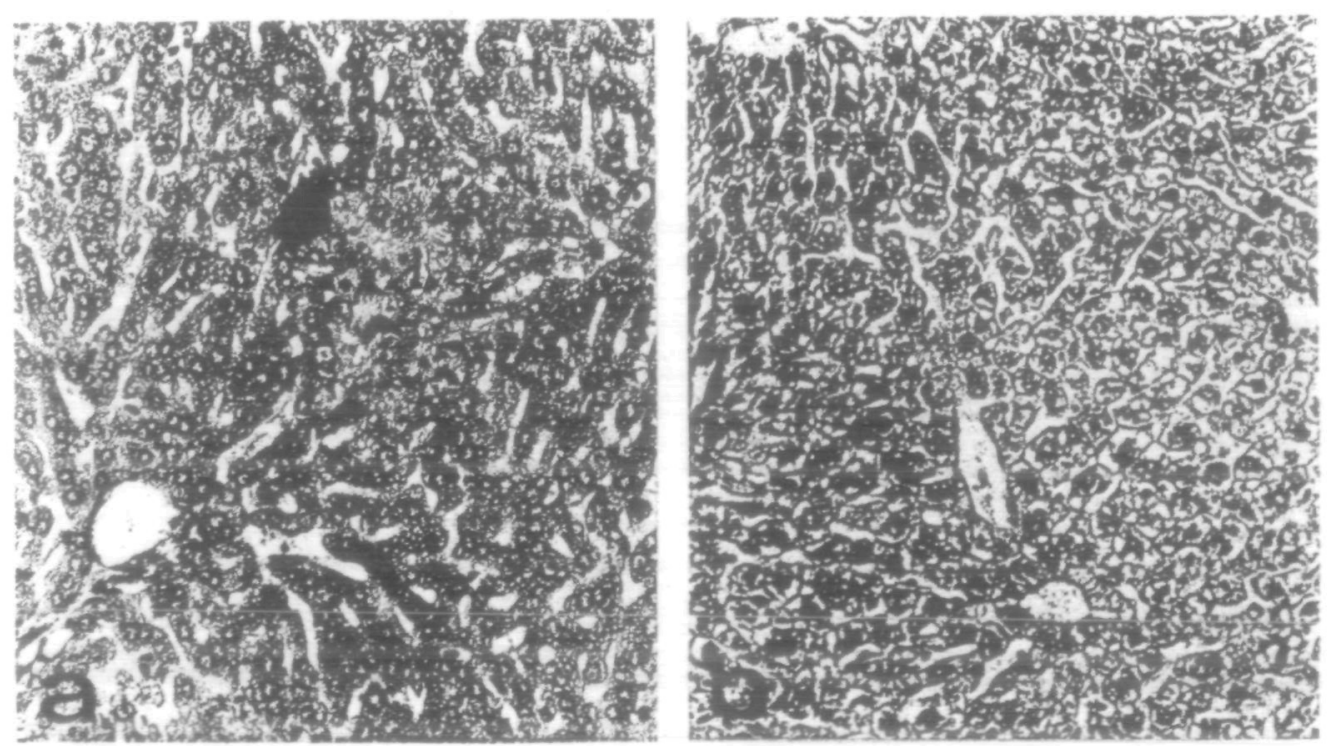

Figure 1. Histological sections of the livers of control (a) and treated (b) mice ( $200 \mathrm{mg} / \mathrm{kg} /$ day) five days after infection with $10^{5}$ tachyzoites of the RH strain of $T$. gondii. Arrow indicates focus of necrosis. Magnification $\times 160$. 
Table II. Effect of minocycline on the number of brain cysts in $T$. gondii-infected mice

\begin{tabular}{lcc}
\hline $\begin{array}{l}\text { Drug } \\
\text { dose (mg/kg per day)) }\end{array}$ & Number of mice & $\begin{array}{c}\text { Mean brain cysts/ } \\
\text { mice } \pm \text { SEM }^{a}\end{array}$ \\
\hline None & 10 & $981 \pm 78$ \\
Minocycline (50) & 10 & $660 \pm 82^{b}$ \\
\hline
\end{tabular}

The mean number \pm S.E.M. of brain cysts at the time of starting experiments was $390 \pm 28$ (for five mice).

${ }^{b} P<0.02$, as compared with control mice.

$8.2 \mathrm{~h}$ after 50 and $100 \mathrm{mg} / \mathrm{kg}$, respectively. Presence of the drug was still detected $16 \mathrm{~h}$ after administration of the higher dose (Figure 2).

\section{Discussion}

Minocycline protected and cured mice lethally infected with a high inoculum of the virulent RH strain of $T$. gondii. The potent effect of minocycline on $T$. gondii was further documented by histological studies which showed that tissue damage seen in the untreated controls was completely avoided in the treated mice. This confirms and extends the findings of Tabbara et al. (1982) who were able to protect $71 \%$ of mice infected with $7 \times 10^{5} \mathrm{~T}$. gondii $\mathrm{RH}$ strain parasites. The reason these authors were unable to protect all the mice in their studies seems to be due to the extremely high parasite inoculum used which was seven times more than in our study. The better cure rate obtained with the twice-a-day dosing compared with the once-a-day regimen may well be related to a more sustained antibiotic coverage as shown by the serum

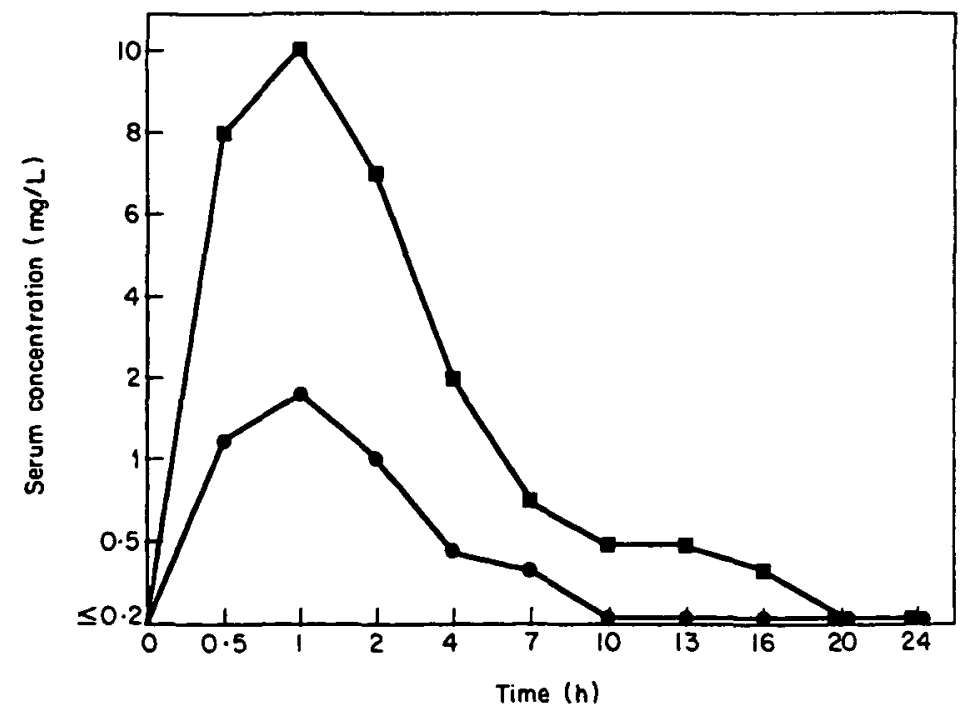

Figure 2. Mean serum pharmacokinetics of minocycline in normal Swiss Webster mice after single peroral doses of $50 \mathrm{mg} / \mathrm{kg}(\mathbf{O})$ and $100 \mathrm{mg} / \mathrm{kg}(\mathbf{D})$. There were three mice per each data point. 
pharmacokinetic curves. A close comparison between murine and human pharmacokinetics is not feasible from the available data. However, minocycline serum concentrations associated with full protection of the mice were in the range of serum concentrations achievable in humans where peak levels have been found at $8.75 \mathrm{mg} / \mathrm{l}$ after a single iv infusion of $100 \mathrm{mg}$ of minocycline (Welling et al., 1975). Pyrimethamine at $8.5 \mathrm{mg} / \mathrm{kg}$ did not enhance significantly the cure rate obtained with $100 \mathrm{mg} / \mathrm{kg}$ per day of minocycline. This observation may suggest either a lack of synergism or additive effect between the two compounds, or insufficient penetration of pyrimethamine at the dose tested into the brains of the infected mice.

In our chronic infection model, fewer brain cysts were counted in the minocycline treated than untreated animals, suggesting that minocycline had reached brain tissue. Since, in the treated animals, less cysts were counted at initiation of therapy than after therapy we assume that minocycline had an inhibitory preventive effect rather than an actual toxoplasmacidal therapeutic effect. Minocycline is highly lipophilic and diffuses into the CSF in significant amounts with concentrations that vary from $15 \%-65 \%$ of the blood concentrations (McDonald et al., 1973). The concentration in human brain tissues of minocycline after oral or iv administrations is not known, but minocycline has been found to achieve a concentration of about $2.5 \mu \mathrm{g} / \mathrm{g}$ in the brains of dogs after an iv infusion of a loading dose of $5 \mathrm{mg} / \mathrm{kg}$ over 10 to $30 \mathrm{~min}$ followed by a continuous infusion of $1 \mathrm{mg} / \mathrm{kg}$ per h during $3 \mathrm{~h}$ (Barza et al., 1975).

The mechanism of action of minocycline on $T$. gondii is unclear at this time. As suggested by previous work from our laboratory, some inhibitors of protein synthesis (i.e. macrolides and tetracycline analogues) possess different degrees of anti-Toxoplasma activity (Chang \& Pechère, 1987, 1988; Chang, Rudareanu \& Pechère, 1988; Chang et al., 1990). However, amongst those drugs, and on a weight-to-weight basis, minocycline appears to be the most active therapeutic agent in the mouse model of acute toxoplasmosis.

In conclusion, our studies demonstrate the potent activity of minocycline in murine infections caused by $T$. gondii. The possibility of using minocycline in the treatment of toxoplasmic infections, including encephalitis, in nonpregnant patients suffering from AIDS, deserves consideration.

\section{Acknowledgements}

We thank Dr I. R. Vladoianu and D. Arsenijevic for technical assistance. This work was supported in part by grant 32-25800.88 from the Swiss National Science Foundation.

\section{References}

Barza, M., Brown, R. B., Shanks, C., Gamble, C. \& Weinstein, L. (1975). Relation between lipophilicity and pharmacological behavior of minocycline, doxycycline, tetracycline, and oxytetracycline in dogs. Antimicrobial Agents and Chemotherapy 8, 713-20.

Chang, H. R., Comte, R. \& Pechère, J.-C. (1990). In vitro and in vivo effects of doxycycline on Toxoplasma gondii. Antimicrobial Agents and Chemotherapy 34, 775-80.

Chang, H. R. \& Pechère, J.-C. F. (1987). Effect of roxithromycin on acute toxoplasmosis in mice. Antimicrobial Agents and Chemotherapy 31, 1147-9.

Chang, H. R. \& Pechère, J.-C. F. (1988). In vitro effects of four macrolides (roxithromycin, spiramycin, azithromycin [CP-62, 993], and A-56268) on Toxoplasma gondii. Antimicrobial Agents and Chemotherapy 32, 524-9. 
Chang, H. R., Rudareanu, F. C. \& Pechère, J.-C. (1988). Activity of A-56268 (TE-031), a new macrolide, against Toxoplasma gondii in mice. Journal of Antimicrobial Chemotherapy 22, $359-61$.

Glatt, A. E., Chirgwin, K. \& Landesman, S. H. (1988). Treatment of infections associated with human immunodeficiency virus. New England Journal of Medicine 318, 1439-48.

Leport, C., Raffi, F., Matheron, S., Katlama, C., Regnier, B., Saimot, A. G. et al. (1988). Treatment of central nervous system toxoplasmosis with pyrimethamine/sulfadiazine combination in 35 patients with the acquired immunodeficiency syndrome. American Journal of Medicine 84, 94-100.

McCabe, R. \& Remington, J. S. (1988). Toxoplasmosis: the time has come. New England Journal of Medicine 318, 313-5.

McDonald, H., Kelly, R. G., Allen, E. S., Noble, J. F. \& Kanegis, L. A. (1973). Pharmacokinetic studies on minocycline in man. Clinical Pharmacology and Therapeutics 14, 852-61.

Remington, J. S. \& Cavanaugh, E. N. (1965). Isolation of the encysted form of Toxoplasma gondii from human skeletal muscle and brain. New England Journal of Medicine 273, $1308-10$.

Tabbara, K. F., Sakuragi, S. \& O'Connor, G. R. (1982). Minocycline in the chemotherapy of murine toxoplasmosis. Parasitology 84, 297-302.

Welling, P. G., Shaw, W. R., Uman, S. J., Tse, F. L. S. \& Craig, W. A. (1975). Pharmacokinetics of minocycline in renal failure. Antimicrobial Agents and Chemotherapy 8, 532-7.

(Received 24 September 1990; accepted 22 January 199I) 